\title{
Analysis of factors influencing consumer's purchase intention in social commerce: The mediator role of trust
}

\section{Necip Karakurt ${ }^{\mathrm{a}^{*}}$ and Pelin Bayram ${ }^{\mathrm{b}}$}

${ }^{a}$ Girne American University - Faculty of Business and Economics, North Cyprus, via Mersin 10 Turkey

\section{H R O N I C L E}

Article history:

Received: March 29, 202

Received in revised format: April

27,2021

Accepted: May 24, 2021

Available online: May 24, 2021

Keywords:

Social commerce

Purchase intention

Habit

Trust

Social influence

\begin{abstract}
A B S T R A C T
It is considered that determining the factors influencing the purchase intentions of customers in the field of social commerce by taking into account the cultural structures specific to each region can give highly valuable feedback to companies in the commercial field where competition has considerably increased. To this end, in the present study, it was aimed to propose and test out a structural model for the factors of social commerce constructs, social influence, habit and trust, which affect the purchase intentions of consumers. The study group of the research consisted of 447 Facebook users who live in North Cyprus. The scale form used as the data collection tool in the study consisted of 6 parts. In the first part of the scale, closed-ended questions were asked to determine the socio-demographic characteristics of the participants. The other parts of the scale consisted of 4 items about social commerce constructs, 4 items about habit, 3 items about social influence, 4 items about trust and 3 items about purchase intention. The reliability coefficients for the scales ranged between 0.79 and 0.92 . These results indicated that the reliability coefficients were at the desired level. Socio-demographic variables were summarized using descriptive statistics, frequency and percentage distribution. First, normality test analyses were performed on the scales, and it was concluded that the data showed a normal distribution (kurtosis and skewness values varied between $+2 /-2$ ). Following the normality test, the measurement model was tested. Within the framework of a structural model proposed regarding the factors influencing the purchase intention of customers who shop through social commerce, it was concluded that habit, social influence and social commerce constructs had a significant effect on purchase intention. It was also concluded that habit and social commerce constructs significantly influenced purchase intention through trust.
\end{abstract}

(C) 2021 by the authors; licensee Growing Science, Canada.

\section{Introduction}

Changes that have occurred in science and technology have brought about radical novelties in the lives of both individuals and businesses. In parallel with the mentioned developments, the Internet, one of the most important communication channels of this age, has come to be used in many business areas in daily life. In the early 2000 s, the Internet was used for basic processes such as accessing information, communication and sending emails. Subsequent to this period, the Internet has become a new and different medium that can be used for different purposes such as education, socializing and shopping, and this change has introduced a new way of doing business for companies. Geographical borders have now disappeared, and a new economic system has emerged. As a result, businesses have begun to gain many advantages in a competitive environment, such as large customer potential, cost reduction and two-way communication. Hence, major differences have started to arise between today's commerce and traditional commerce. 


\subsection{Electronic commerce and its differences from traditional commerce}

Commerce, which conceptually means trading activity carried out for profit, has taken its current form over time with the developing technology. With the developments in computer technology, finance, transportation and mass media, and with the use of the web and the Internet in a digitally supported environment, commercial transactions have also started to take place in an electronic environment (Özbay \& Devrim, 2000, pp. 12-14). The concept of electronic commerce has now become pronounced alongside the concept of traditional commerce. Certain definitions of electronic commerce in the literature are indicated below.

- According to the definition offered by World Trade Organization (WTO), electronic commerce is the production, marketing, sales and distribution of products and services over telecommunication networks (http://www.wto.org).

- International Trade Center (ITC) defines electronic commerce as the distribution, marketing and sales of products and services in an electronic environment (Bucakl1, 2007, p. 42).

Although electronic commerce is different from traditional commerce, it mostly benefits from the principles of traditional commerce. Therefore, electronic commerce is not an alternative to traditional commerce. However, it should not be forgotten that commerce is gradually moving away from the traditional structure and procedures, and that it has been carried to the electronic environment and has introduced new principles and rules. It can be stated that the most important difference between electronic commerce and traditional commerce is related to the breadth of the markets (Şimşek, 2012). In e-commerce, the marketplace is on a virtual platform. With the transfer of the buyer-seller relationship to the virtual environment, traditional mediation has disappeared. Being used alongside electronic commerce, the concept of marketing, one of the important issues of traditional business management, has adapted to this change, and thus the concept of online marketing, the new marketing approach of the digital age, has come into our lives. Markets have historically been defined as physical spaces which allow buyers and sellers to meet at a certain time and in a certain place, and where they start to communicate by specifying their willingness to buy and sell. These markets are also available today. However, the developments in communication technology, and the Internet, the use of which is constantly increasing, are an important source of obtaining information about markets, products, customers, suppliers and competitors for businesses to safely do their activities in a constantly increasing competitive environment (Deeter-Schmelz et al., 2001; Roberts \& Mackay, 1998). These developments have also been significantly affected by the widespread use of social media. Social media tools, which motivate a consumption culture based on sharing, have become platforms where users can consult each other about businesses and brands, make comments and remarks, apart from using them for entertainment purposes. In the face of this change, businesses have started to take part in these platforms in order to benefit from the effective communication aspect of social media, to influence their existing and potential customers and to engage in their marketing activities. Thus, social media has become a new communication channel, a new marketing channel, an important source of information and even a new sales channel for businesses (Kurcova \& Enginkaya, 2015). This situation has also led to the emergence of the concept of social commerce.

\subsection{Social commerce}

Social media networks are defined as web-based virtual communities where users can establish interactive relationships, share content, influence the shared content with comments and similar remarks (Boyd \& Ellison, 2007, p. 104). Social networks, which are used as platforms where the activities included in the definition at the beginning of the process are done, have recently become commercial centers. Although in general terms commerce on social media has the characteristics of electronic commerce, there are differences between them. Electronic commerce refers to the production, promotion, sales, insurance, distribution and payment transactions for products and services through computer networks (Standifer \& Wall, 2003, p. 54). As can be understood from the definition, it is sufficient for the transactions to be conducted on the Internet for commercial activities to be carried out. On the other hand, commerce on social media is a platform where people interact collectively beyond computer networks, and although this platform is located in the Internet environment, it has characteristic dynamics quite different from the Internet. The stressed point is that traditional one-way media has evolved from monologue to dialogue and transformed into an interactive commerce platform, thanks to web-based applications and web 2.0 technology. This process has introduced the concept of social commerce. Although social commerce conceptually involves friend recommendations, product reviews and product ratings, it has also included marketing activities for consumers and active participation of consumers with the development of social media, and has begun to be widely discussed in the literature (Stephen \& Toubia, 2010). Marsden (2010) considered social commerce as the intersection of electronic commerce and social media, interpreting it as the monetization of social media through electronic commerce and its transformation into a source of income. In electronic commerce, the interaction between the buyer and seller is more limited, while this interaction is more active in social commerce. Besides, recommendations, comments and ratings in commerce on social media allow us to obtain different information about the product and can affect the decision-making mechanism of the buyer (Kircova \& Enginkaya, 2015). One of the social networks where social commerce takes place is Facebook. Today, many companies around the world have become a part of this transformation with their fan pages on Facebook and their marketing activities on these pages. The combination of many elements of the process such as buyers, sellers, suppliers and entrepreneurs on a single platform brings along many advantages for both producers and consumers. Structural features on Facebook, such as sharing of image and audio files, comments and likes on the shared content, fan pages of trademarks, comments and experiences of consumers on products and 
services, target market segmentation for companies and advertisers, differentiate Facebook from other social networks in terms of the development of social commerce. These products and services are the pioneers of new social commerce initiatives, and the foundations of innovative social commerce practices are based on the concepts of "friendship" and "word of mouth marketing" (Rad \& Benyoucef, 2010, p. 19).

\subsection{Consumer behavior in social commerce}

Various studies have been conducted on social commerce, which is a newly introduced concept in the literature. As in electronic commerce, the reasons that lead consumers to buy have been the subject of research, and in addition to benefiting from the variables used in electronic commerce, the studies have also discussed the issues that differentiate social commerce. Within this scope, the experiences of consumers who shop through various social media channels have been addressed. By analyzing consumer behavior, it becomes possible to find answers to such questions as why consumers buy products and services, when, where, how often and in what quantity and method they buy them, and how they use them. A marketing mix that will satisfy the wants and needs of the consumer can only come out with the answers of these questions. Thus, if consumer behavior is understood in all aspects, it becomes possible to create a successful marketing strategy and charm the consumer with the collected information (Odabaşı \& Barış, 2014, pp. 16-17). For this reason, it is necessary to examine in detail the factors that influence consumer behavior and also which factors the behavior is related to (Kotler \& Armstrong, 2005, p. 137).

\subsubsection{The factors that influence consumer behavior}

The factors that exist in traditional commerce and induce the consumer generally influence consumer behavior in social commerce. These factors are mentioned below:

1- Psychological Factors: Learning, motivation and perception, attitude, personality are factors that influence the consumer psychologically.

2- Socio-Cultural Factors: Culture, family, lifestyle and reference groups influence consumer behavior socially and culturally (Kotler, 2000, p. 168).

3- Personal Factors: Gender, age, role and status, education and income level are personal factors that influence consumer behavior (Kotler, 2000, p. 167).

In addition to this approach, the factors that explain this structure and influence the buying behavior of the consumer have begun to be investigated with the increase in social commerce. As defined above, social commerce is a concept that was introduced to describe an interactive social network that can enable consumers to exchange information with each other about products on various online platforms, as well as express their opinions about these products (Chen et al., 2011). In this respect, social commerce has become a reference point that provides information to users, and the reviews and comments of other participants have become an important factor in the buying process (Wang \& Zhang, 2012). The comments and reviews of other users have come to influence the consumers' perceptions and trust in the product. These two factors are among the most important factors influencing the buying behavior of consumers. The trust variable has been used many times in the studies conducted to explain the buying behavior in electronic commerce and social commerce. In most of these studies, it was found that electronic trust had a significant effect on purchase intention or repeated buying desire (Hajli, 2015; Hsu et al., 2017; Kim \& Park, 2013; Shin, 2010). It was also found that the trust variable had a positive effect on purchase intention (Che et al., 2017; Kusumah, 2015; Prasertsith et al., 2015). Hajli and Sims (2015) defined social commerce as a new flow in e-commerce where social factors are the determinant of this phenomenon and where consumers are empowered. Hence, it is said that all social structures on this platform influence the buying behavior. Online communities, forums, ratings, reviews and recommendations have begun to be expressed as the factors of the social commerce constructs (Chen, Xu \& Whinston, 2011; Hajli, 2015; Senecal \& Nantel, 2004). The studies on the factors of ratings and reviews, recommendations and guidance, forums and communities, which have started to be considered as the components of the social commerce constructs, have become widespread, addressing the positive effects of these factors on the buying behavior (Curty \& Zhang, 2013; Kim \& Park, 2013; Stephen \& Toubia, 2010; Zhang, Gupta \& Zhao, 2014). However, when the social and cultural factors are considered, it may be wrong to think that the studies on the factors of ratings and reviews, recommendations and guidance, forums and communities are similar worldwide. In order to achieve the desired level of commercial success, it is of great importance for commercial companies to determine the influences of these social commerce constructs that affect the buying behavior of consumers in the regions they provide services, as these processes affect student trust and guide the buying process.

In brief, social commerce on social media platforms constitutes a dynamic and reliable environment which involves family, friends and other acquaintances, and where instant content is created, products and services are traded, and user comments, ratings, positive or negative impressions, and experiences related to the product or service are shared. Thus, thanks to the shared experiences of social media users regarding the product and service, the shopping time is shortened and the shopping activity becomes much more reliable. Comments, likes and recommendations regarding the product or service provided by family members and friends in the network, unlike in a typical electronic commerce website, positively affect the reliability of the shopping activity (Rubel, 2011; as cited, Kara, 2012). The current study, aiming to propose a model for the factors influencing purchase intention, also included the understudied habit factor. Certain studies were conducted on the habit of 
using technology (Venkatesh et al., 2012; Wang et al., 2013). However, unlike these studies, the present study investigated the influence of habit on purchase intention in order to make a unique contribution to the field. Determining the influences of habit and the other factors on purchase intention by taking into account the cultural structures specific to each region can give highly valuable feedback to companies in the commercial field where competition has considerably increased. Hence, the sample of the present study consisted of the participants from North Cyprus. Furthermore, creating a structural model with a holistic understanding instead of putting forward the effects of all variables on each other one by one will make great contributions to the success and reliability of the shopping activity. The current study conducted in the light of these motives, it was aimed to propose and test out a structural model for the factors of social commerce constructs, social influence, habit and trust, which affect the purchase intentions of consumers. Within the framework of this aim, the following hypotheses were constructed:
$\mathbf{H}_{1}$ : Habit has a positive effect on purchase intention.
$\mathbf{H}_{2}$ : Social commerce constructs have a positive effect on purchase intention.
$\mathbf{H}_{3}$ : Social influence has a positive effect on purchase intention.
$\mathbf{H}_{4}$ : Habit has a positive effect on trust.
H5: Social commerce constructs have a positive effect on trust.
H6: Social influence has a positive effect on trust.
H7: Trust has a positive effect on purchase intention.
H8: Trust mediates the relationship between habit and purchase intention.
H9: Trust mediates the relationship between social commerce constructs and purchase intention.
$\mathbf{H}_{10}$ : Trust mediates the relationship between social influence and purchase intention.

\section{Material and methods}

Structural Equation Modeling was used in this study to test out a structural model for the factors of social commerce constructs, social influence, habit and trust, which affect the purchase intentions of consumers. Structural Equation Modeling is a method generally used in political science and marketing studies, and is applied to determine the causal or correlational relationship between observable and latent variables. Structural Equation Modeling analysis is a method preferred in such fields as psychology, sociology and education. It is formed by the combination of factor analysis and regression analysis (Karagöz \& Ağbektaş, 2016).

\subsection{The proposed research}

The model created in accordance with the aim of the research included the variables of social commerce constructs, social influence, habit, and trust and purchase intention. The variables in the research model and the relationship between these variables were constructed by paying attention to the relevant literature. The research model is presented in Fig. 1.

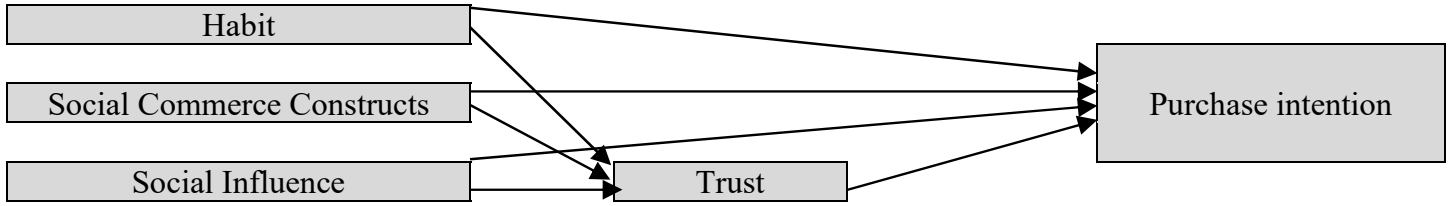

Fig. 1. The Research Model

\subsection{The study group of the research}

The study group of the research consisted of 447 Facebook users who live in North Cyprus. The demographic characteristics of the participants are presented in Fig. 2.

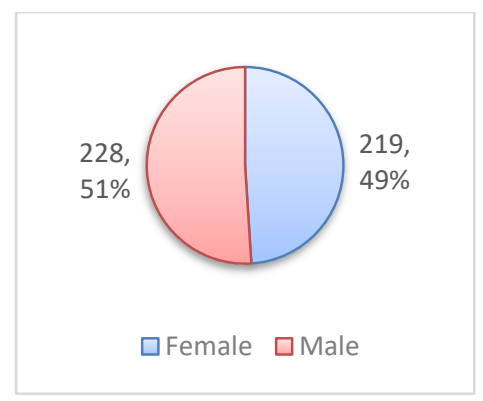

Gender

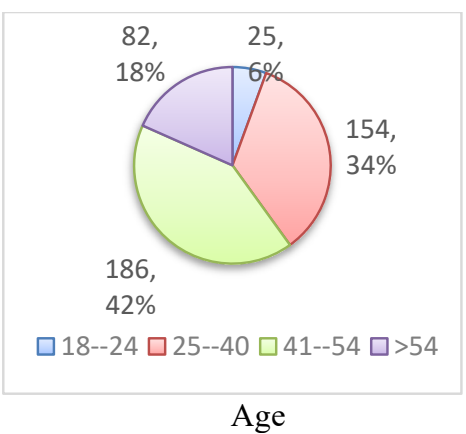

Age

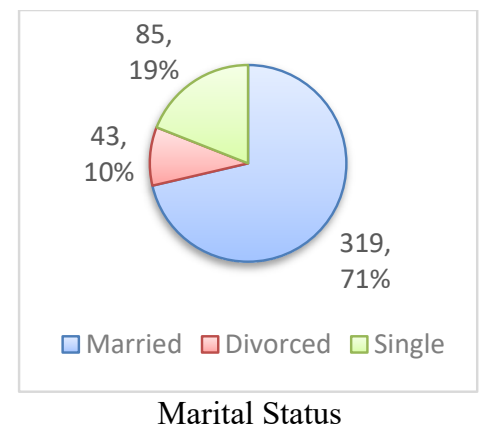

Marital Status 


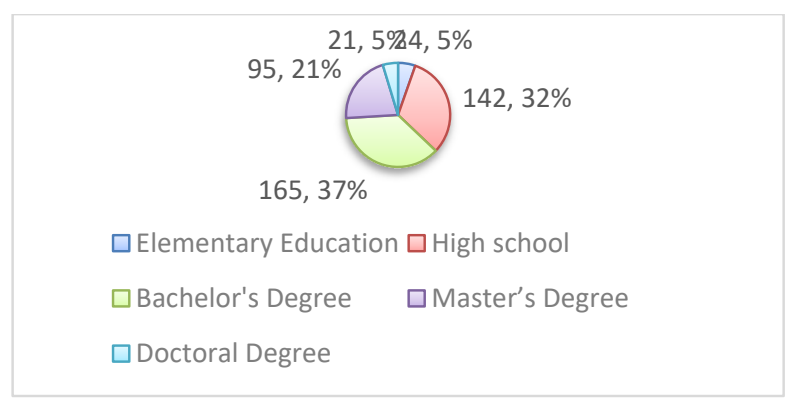

Educational background

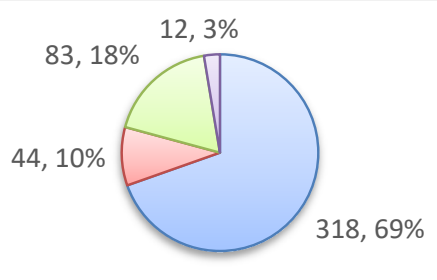

$\square$ Working $\square$ Not working $\square$ Retired $\square$ Student

Fig. 2. The Demographic Characteristics of the Participants

\subsection{Data Collection tool and its application}

In the study, the scale form was used as the data collection tool. Previously developed scales that were tested for validity and reliability were preferred in the study. The scale used in the fieldwork consisted of 6 parts. In the first part of the scale, closedended questions were asked in order to determine the socio-demographic characteristics of the participants. The other parts of the scale consisted of 4 items about social commerce constructs, 4 items about habit, 3 items about social influence, 4 items about trust and 3 items about purchase intention.

- $\quad$ The Habit scale, developed by Escobar-Rodríguez \& Carvajal-Trujillo (2013), consists of 4 items and the Cronbach's alpha reliability coefficient was found to be .82 . In the present study, the reliability coefficient was found to be .92 .

- $\quad$ The Social Commerce Constructs scale, developed by Hajli (2015), consists of 4 items and the Cronbach's alpha reliability coefficient was found to be .85 . In the present study, the reliability coefficient was found to be .89 .

- The Purchase Intention scale, developed by Alotaibi, Alkhathlan and Alzeer (2019), consists of 3 items and the Cronbach's alpha reliability coefficient was found to be .85 . In the present study, the reliability coefficient was found to be 91 .

- $\quad$ The Trust scale, developed by Alotaibi, Alkhathlan and Alzeer (2019), consists of 3 items and the Cronbach's alpha reliability coefficient was found to be .83 . In the present study, the reliability coefficient was found to be .79 .

- The Social Influence scale, developed by Escobar-Rodríguez \& Carvajal-Trujillo (2013), consists of 3 items and the Cronbach's alpha reliability coefficient was found to be .75 . In the present study, the reliability coefficient was found to be .91 .

The relevant scale was converted into an electronic form and applied to the participants via Facebook.

\subsection{Data analysis}

The data obtained in the study were analyzed using SPSS (Statistical Package for Social Sciences for Windows 21.00) and AMOS (Analysis of Moment Structures 26.00) programs. The socio-demographic variables were summarized using descriptive statistics, frequency and percentage distribution. First, normality test analysis was performed on the scales, and it was concluded that the data showed a normal distribution (kurtosis and skewness values varied between $+2 /-2$ ). Following the normality test, the measurement model was tested. Since the fit values in the measurement model $(\mathrm{CMIN} / \mathrm{DF}=2,598$, $\mathrm{RMSEA}=.060, \mathrm{GFI}=.925, \mathrm{CFI}=970$ ) were realized between the desired values, the researcher moved onto the second stage and the first structural equation model was constructed. The fit values of this model were also found at the desired level $(\mathrm{CMIN} / \mathrm{DF}=2,823, \mathrm{RMSEA}=.064, \mathrm{GFI}=.936, \mathrm{CFI}=976)$. At the last stage, the second structural equation model was constructed and the fit values were found to be at the desired level (CMIN/DF=2,598, RMSEA=.060, GFI=.925, CFI=,970). Path coefficients were analyzed in both models and statistical significance level was investigated.

\section{Results}

In this part, the data obtained during the research process is presented. In Fig. 3, the measurement model of the data is shown.

When Fig. 2 is examined, it is observed that the fit values in the measurement models are between the desired values $(\mathrm{CMIN} / \mathrm{DF}=2,598, \mathrm{RMSEA}=.060, \mathrm{GFI}=.925, \mathrm{CFI}=, 970)$, which means that the model is compatible. Statistical data on all path coefficients are presented in Table 2.

In Table 2, both standardized and non-standardized analysis results of the obtained path coefficients are shown. It was concluded that all path coefficients of the research data were statistically significant $(p<.001)$ (see Table 1). In Fig. 4, the structural equation model constructed for the first three hypotheses is shown. 
Table 1

Statistical Data on Path Coefficients

\begin{tabular}{|c|c|c|c|c|c|c|}
\hline \multicolumn{2}{|c|}{ Measurement Model } & B1 & $\mathrm{B} 2$ & S.E. & C.R. & $\mathrm{P}$ \\
\hline Habit1 & \multirow{4}{*}{ Habit } & .863 & 1.000 & & & \\
\hline Habit2 & & .847 & .926 & .036 & 25.698 & $<0,001$ \\
\hline Habit3 & & .845 & 1.113 & .032 & 25.864 & $<0,001$ \\
\hline Habit4 & & .915 & 1.110 & .034 & 26.899 & $<0,001$ \\
\hline Constructs1 & \multirow{4}{*}{ Constructs } & .795 & 1.000 & & & \\
\hline Constructs2 & & .872 & 1.115 & .059 & 19.956 & $<0,001$ \\
\hline Constructs 3 & & .877 & 1.120 & .060 & 19.825 & $<0,001$ \\
\hline Constructs 4 & & .774 & .945 & .060 & 17.768 & $<0,001$ \\
\hline Influence1 & \multirow[t]{3}{*}{ Influence } & .820 & 1.000 & & & \\
\hline Influence2 & & .934 & 1.143 & .030 & 32.700 & $<0,001$ \\
\hline Influence3 & & .921 & 1.148 & .036 & 24.529 & $<0,001$ \\
\hline Intention 1 & \multirow{3}{*}{ Intention } & .874 & 1.000 & & & \\
\hline Intention 2 & & .915 & 1.063 & .038 & 27.903 & $<0,001$ \\
\hline Intention3 & & .880 & 1.035 & .040 & 25.874 & $<0,001$ \\
\hline Trust1 & \multirow{4}{*}{ Trust } & .806 & 1.000 & & & \\
\hline Trust2 & & .703 & .896 & .056 & 9.031 & $<0,001$ \\
\hline Trust3 & & .432 & .571 & .050 & 15.954 & $<0,001$ \\
\hline Trust4 & & .825 & 1.132 & .046 & 19.064 & $<0,001$ \\
\hline
\end{tabular}

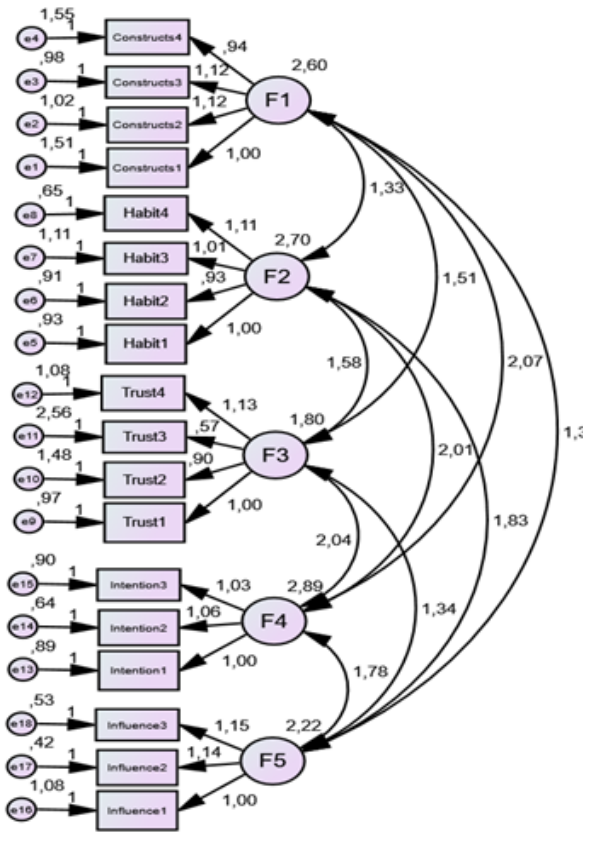

Fig. 3. Measurement Model

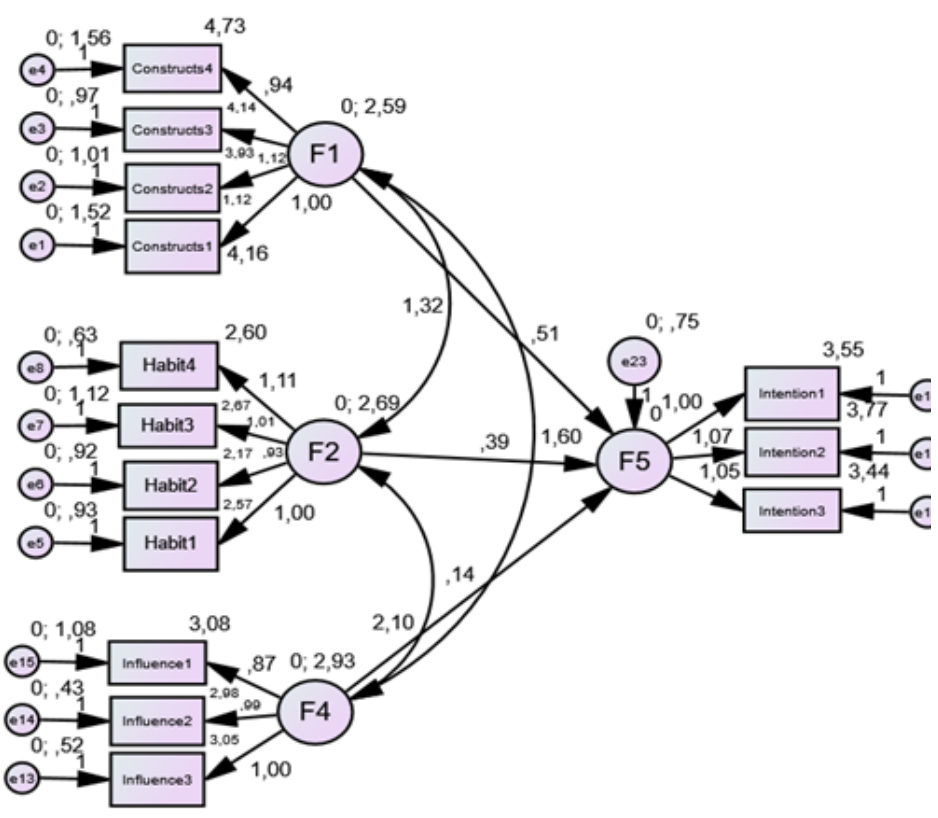

Fig. 4. Structural Model 1

Based on the results obtained in the constructed structural model, it was observed that the model was compatible and the model fit indices were between the desired values $(\mathrm{CMIN} / \mathrm{DF}=2,823, \mathrm{RMSEA}=.064, \mathrm{GFI}=.936, \mathrm{CFI}=, 976)$. Statistical data on all path coefficients are presented in Table 2. In this structural model, the first three hypotheses were tested. The data on these tests are shown in Table 2.

Table 2

Analysis Results for Structural Model 1 (SEM1)

\begin{tabular}{llllllll}
\hline \multicolumn{2}{c}{ Measurement Model } & B1 & B2 & S.E. & C.R. & P \\
\hline Intention & Habit & .374 & .385 & .050 & 7,196 & $<0,001$ \\
Intention & Constructs & .487 & .512 & .053 & 10.690 & $<0,001$ \\
Intention & Influence & .137 & .138 & .056 & 2.579 & $<0,001$ \\
\hline
\end{tabular}

In SEM 1, the path coefficient between purchase intention and habit was found to be statistically significant ( $p<, 001)$. This result validated the hypothesis "Habit has a positive effect on purchase intention". In SEM 1, the path coefficient between purchase intention and social commerce constructs was found to be statistically significant ( $<<, 001)$. Thus, the H2 hypothesis "Social commerce constructs have a positive effect on purchase intention" was also validated. Lastly, in SEM 1, the path coefficient between purchase intention and social influence was also found to be statistically significant ( $p<, 001)$. This result 
also validated the $\mathrm{H} 3$ hypothesis "Social influence has a positive effect on purchase intention". In Fig. 5, Structural Model 2 constructed within the scope of the research is shown. This model was constructed to test whether trust had a mediating effect on the relationship between habit, social commerce constructs and social influence, and purchase intention.

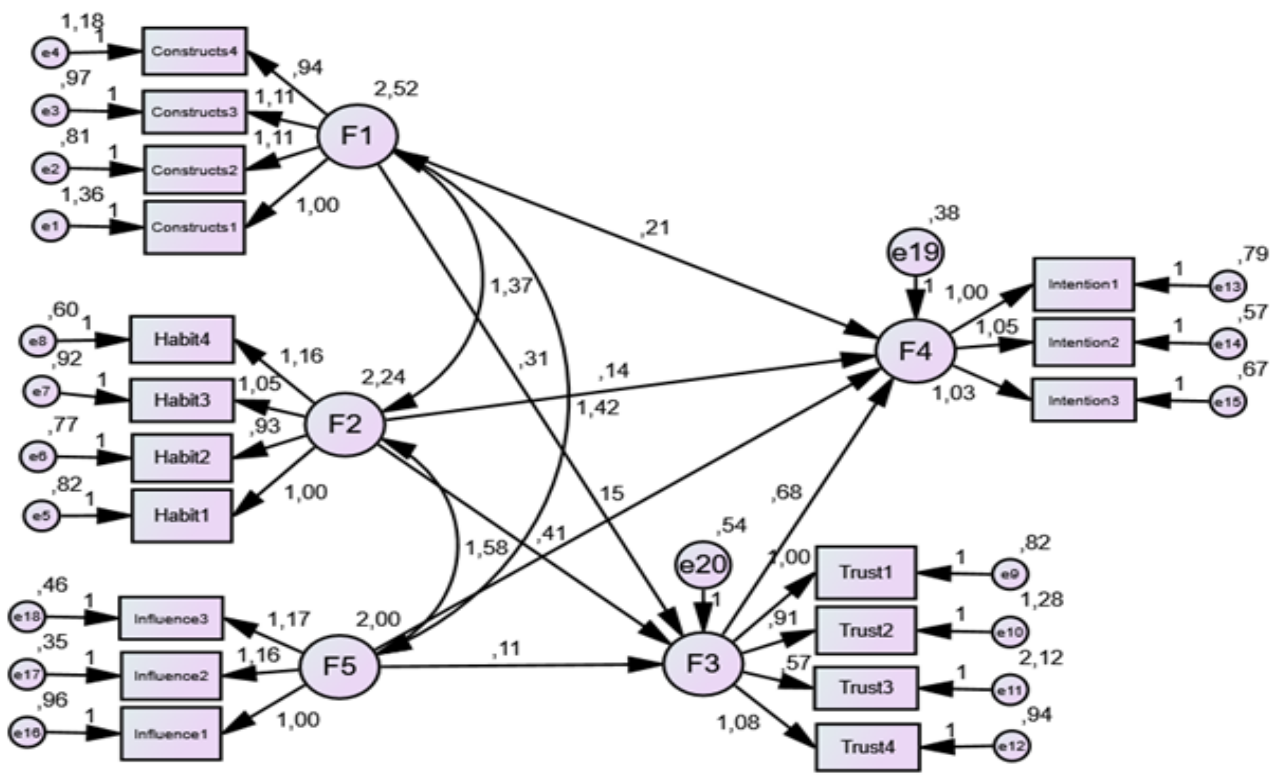

Fig. 5. Structural Model 2 (SEM2)

Based on the results obtained in the constructed Structural Model 2, it was observed that the model was compatible and the model fit indices were between the desired values $(\mathrm{CMIN} / \mathrm{DF}=2,598, \mathrm{RMSEA}=.060, \mathrm{GFI}=.925, \mathrm{CFI}=, 970)$. Statistical data on all path coefficients are presented in Table 4. In this structural model, 7 hypotheses were tested. The data on these tests are shown in Table 3.

Table 3

Analysis Results for Structural Model 2 (SEM2)

\begin{tabular}{|c|c|c|c|c|c|c|}
\hline \multicolumn{2}{|c|}{ Measurement Model } & B1 & B2 & S.E. & C.R. & $\mathbf{P}$ \\
\hline Intention & Habit & .127 & .137 & .052 & 2,331 & $<0,01$ \\
\hline Intention & Constructs & .209 & .213 & .055 & 5.059 & $<0,001$ \\
\hline Intention & Influence & .97 & .111 & .050 & 1.545 & .082 \\
\hline Intention & Trust & .561 & 679 & ,089 & 8.609 & $<0,001$ \\
\hline Trust & Habit & .461 & .412 & .046 & 6.765 & $<0,001$ \\
\hline Trust & Constructs & .372 & .313 & .047 & 8.067 & $<0,001$ \\
\hline Trust & Influence & .98 & .111 & .051 & 1.679 & .082 \\
\hline
\end{tabular}

In SEM 2, the path coefficient between trust and habit was found to be statistically significant $(\mathrm{p}<, 001)$. This result validated the H4 hypothesis "Habit has a positive effect on trust". In SEM 2, the path coefficient between trust and social commerce constructs was found to be statistically significant $(\mathrm{p}<, 001)$. Thus, the H5 hypothesis "Social commerce constructs have a positive effect on trust" was also validated. In SEM 2, the path coefficient between trust and social influence was not found to be statistically significant $(\mathrm{p}=.082)$. This result shows that the H6 hypothesis "Social influence has a positive effect on trust" was not validated. In SEM 2, the path coefficient between trust and purchase intention was found to be statistically significant $(\mathrm{p}<, 001)$. This result falsified the H7 hypothesis "Trust has a positive effect on purchase intention". When the results regarding whether trust has a mediating role between the other variables and purchase intention are examined, it is seen that the direct effect $(\mathrm{B} 1=.374)$ between habit and purchase intention $(\mathrm{SEM} 1)$ decreases $(\mathrm{B} 1=.127)$ after trust is added to the model (SEM2). This result indicates that trust has a mediating role in the effect between habit and intention and validates the H8 hypothesis "Trust mediates the relationship between habit and purchase intention". It is seen that the direct effect $(\mathrm{B} 1=.487)$ between social commerce constructs and purchase intention (SEM1) decreases $(\mathrm{B} 1=.209)$ after trust is added to the model (SEM2). This result indicates that trust has a mediating role in the effect between social commerce constructs and intention and validates the H9 hypothesis "Trust mediates the relationship between social commerce constructs and purchase intention". Although it is observed that the effect $(\mathrm{B} 1=.137)$ between social influence and purchase intention (SEM1) decreases $(\mathrm{B} 1=.97)$ and the effect becomes insignificant after trust is added to the model (SEM2), it is not possible to mention mediation, since the effect of social influence on trust is not statistically significant. This result falsified the H10 hypothesis 
"Trust mediates the relationship between social influence and purchase intention". The results regarding whether the indirect effect of habit and social commerce constructs on purchase intention is statistically significant are presented in Table 4.

Table 4

Statistical Data on Indirect Effect of Habit and Social Commerce Constructs on Purchase Intention

\begin{tabular}{lcccc}
\hline Parameter & B1 & Lower & Upper & p \\
\hline Indirect (Intention-Habit) & .237 & .147 & .346 & $<0,001$ \\
Indirect (Intention-Constructs) & .288 & .195 & .411 & $<0,001$ \\
\hline
\end{tabular}

As seen in Table 4, the indirect effect of both habit and social commerce constructs on purchase intention is statistically significant $(\mathrm{p}<0,001)$.

\section{Discussion}

The results obtained within the scope of the research indicated that habit, social commerce constructs and social influence had a significant effect on purchase intention. Among these three factors, social commerce constructs had the largest effect, followed by the habit factor. This result indicates that, as emphasized in other studies, recommendations in forums and communities on social media significantly influence purchase intention. Similar results have been obtained in the studies conducted to investigate the influences on purchase intention (Hajli, 2015; Hajli \& Sims, 2015; Makmor \& Alam, 2017; Sheikh et al., 2019). Likewise, it was found in this study that customer habits also had a significant influence on purchase intention. In the studies conducted by Sheikh et al. (2017) and Escobar-Rodríguez \& Carvajal-Trujillo (2013), the effect of habit on purchase intention was investigated and it was stated that it had a positive effect. When these three factors were examined, it was found that the least effect was that of the social influence created by the immediate circle. This result reveals that forums and communities on social media influence purchase intention more than our immediate circle. For this reason, taking into account the views of forums and communities on social media and making plans accordingly are important for the commercial success of the companies engaged in social commerce. When the other data obtained during the research process is examined, it is seen that habit and social commerce constructs have a positive effect on trust. This result is considered to stem from the fact that recommendations of forums and communities on social media increase the sense of trust of customers. This also requires trading companies to follow and care about the views of forums and communities on social media, and to provide the relevant updates in line with these views. Ba \& Pavlou (2002) and Hajli (2015) investigated the effects of social commerce constructs on trust in their studies and obtained results parallel to those obtained in the present study. Customer habits are another factor that trading companies should take into account. Regulating habit in favor of the company is an important condition for commercial success, as it will increase purchase intention and trust. Social influence had a low effect on trust, yet this effect was not found to be significant. This result indicates that interaction with the immediate circle does not have a high level of influence on trust and purchase intention in social commerce. Social media, which has come into human life to a considerable extent in recent years, is gradually superseding the immediate circle and increasing its effect on the individual. Considering that these two factors significantly influence purchase intention, it is observed that habit and commerce constructs positively affect trust, and influence purchase intention through trust. Whether or not this effect is significant, and the indirect effect of habit and social commerce constructs on purchase intention were also analyzed within the scope of the research, and the result was significant. This result is an indication that trust has a mediating effect on the influence of habit and social commerce constructs on purchase intention. It was also concluded that trust had a very high level of positive effect on purchase intention. This result is consistent with the results of the studies conducted in this area (Che et al., 2017; Hajli, 2015; Hsu et al., 2017; Kusumah, 2015; Li, 2017; Pınar, Yılmaz \& Güngördü-Belbağ, 2019; Prasertsith et al., 2015; Yılmaz \& Tümtürk, 2015). Considering all the results, it can be said that habit, and communities and forums on social media increase trust in social commerce, and this trust has a significant positive effect on purchase intention. This result is considered as an indication that the factors of social commerce constructs are preferred more than the effect of the immediate circle as a source of trust.

\section{Conclusion}

Within the scope of this research, a structural model was proposed on the factors influencing the purchase intention of customers who shop through social commerce. In the framework of this model, it was concluded that habit, social influence and social commerce constructs had a significant effect on purchase intention, and also, habit and social commerce constructs significantly affected purchase intention through trust. It is hoped that this model will be a guide for companies engaged in social commerce. In order for companies that desire to be successful in social commerce to direct the purchase intentions of customers to their own companies within the framework of this model, it is first of all necessary to take a close interest in the views of the forums and communities on social media and to have a positive effect on that community. Moreover, customer habit should not be ignored and these variables should be taken into account while developing their products. Given that these variables feed trust and that trust has a very high effect on purchase intention, the issue of trust should also be an indispensable element for companies. This research was conducted to determine certain factors influencing the purchase intention of customers. In order to make a contribution to the field of social commerce, it is recommended that such studies be conducted continuously and with different variables, considering the human factor and the rapid variability. 


\section{Limitations and Future Research Directions}

One of the main limitations of this study is that the sample only consisted of the participants living in North Cyprus. This caused the results obtained within the scope of the research to be limited to a certain culture. In future studies, the model can be tested out with other groups in other regions to support the overall findings. Another obvious limitation of this study is that the data was collected from a specific social network. It is recommended to take other social networks into account and to compare the results in future studies. It will be invaluable for future research to pay regard to the limitations mentioned in this research.

\section{References}

Alotaibi, T. S., Alkhathlan, A. A., Alzeer, S. S. (2019). Instagram shopping in Saudi Arabia: what influences consumer trust and purchase decisions? International Journal of Advanced Computer Science and Applications, 10(11).

Ba, S., \& Pavlou, P. A. (2002). Evidence of the effect of trust building technology in electronic markets: Price premiums and buyer behavior. MIS Quarterly, 26(3).

Boyd, D. \& Nicole, B. E. (2007) Social network sites: definition, history, and scholarship journal of computer. Mediated Communication 13, 210-230.

Bucaklı, A. T. (2007). Elektronik Ticaret. Yayımlanmamış yüksek lisans tezi. Kadir Has Üniversitesi /Sosyal Bilimleri Enstitüsü, İstanbul.

Che, J. W., Cheung, C. M., \& Thadani, D. R. (2017, January). Consumer purchase decision in Instagram stores: The role of consumer trust. In Proceedings of the 50th Hawaii International Conference on System Sciences.

Chen, J., Xu, H., \& Whinston, A. B. (2011). Moderated online communities and quality of user-generated content. Journal of Management Information Systems, 28(2), 237-268.

Curty, R.G., \& ve Zhang, P. (2013). Website features that gave rise to social commerce: a historical analysis. Electronic Commerce Research and Applications, 12, 260-279.

Deeter-Schmelz, D. R., Bizzari, A., Graham, R., \& Howdyshell, C. (2001). Business-to-business online purchasing: suppliers' impact on buyers' adoption and usage intent. Journal of Supply Chain Management, 37(4), 4-10.

Escobar-Rodríguez, T., \& Carvajal-Trujillo, E. (2013). Online drivers of consumer purchase of website airline tickets. Journal of Air Transport Management, 32, 58-64.

Hajli, M. (2012). Social Commerce Adoption Model. UK Academy for Information Systems Conference, 16.

Hajli, N. \& Sims, J. (2015). Social commerce: the transfer of power from sellers to buyers. Technological Forecasting and Social Change, 94, May, 350-358

Hajli, N. (2015). Social commerce constructs and consumer's intention to buy. International Journal of Information Management, 35, 183-191.

Hsu, C., Mu-Chen C., Kikuchi, K., \& Machida, I. (2017). Elucidating the determinants of purchase intention toward social shopping sites: a comparative study of Taiwan and japan. Telematics and Informatics, 34, 326-338.

Kara, T. (2012). The transformation of social media to social commerce network: facebook case study. Gaziantep University Journal of Social Sciences. 11(4), 1419-1439.

Karagöz, Y., \& Ağbektaş, A. (2016). Yapısal eşitlik modellemesi ile yaşam memnuniyeti ölçeğinin geliştirilmesi; Sivas İli Örneği. Bartın Üniversitesi İ.̇.B.F. Dergisi, 7(13),

Kırcova, İ., \& Enginkaya, E. (2015). Sosyal Medya Pazarlama, İstanbul: Beta Basım.

Kim, S \& Park, H. (2013). Effects of various characteristics of social commerce (s-commerce) on consumers' trust and trust performance. International Journal of Information Management 33, 318- 332.

Kotler, P. (2000). Marketing management. Prentice Hall International. Inc. The Millennium Edition. New Jersey.

Kotler, P., \& Armstrong, G. (2005). Principles of marketing. 11. Edition, New Jersey.

Kusumah, R. (2015). Analyze the effect of trust, price, quality and perceived risk toward consumer purhase behavior in online shops Instagram. Journal Berkala Ilmiah Efisiensi, 15(5), 355- 366.

Li, C.-Y. (2017). How social commerce constructs influence customers' social shopping intention? An empirical study of a social commerce website. Technological Forecasting \& Social Change, 144, 282-294.

Marsden, P. (2010), Social Commece: Monetizing Social Media, London: Syzygy Group.

Makmor, N. B. \& Alam, S. S. (2017). Attitude towards social commerce: a conceptual model regarding consumer purchase intention and its determinants. International Journal of Economic Research, 14 (22).

Odabaşı, Y. \& Barış, G. (2014). Tüketici davranışı (14.Baskı). İstanbul: MediaCat

Özbay, A. \& Devrim, J. (2000). E-ticaret rehberi. İstanbul: Hayat Yayın

Pınar, M., Yılmaz, K. G. \& Güngördü Belbağ, A. (2019). Sosyal ağlar üzerinden yapılan ticarette tüketici satın alma niyetini etkileyen faktörlerin belirlenmesi: instagram kullanıcıları üzerine bir araştırma. Tüketici ve Tüketim Araştırmaları Dergisi, 11(2), 357-378

Prasertsith, K., Penjira K, \& Penjuree K. (2015). The Factors Affecting Purchase Intention of Fashion Accessories Through Instagram. Conference: The 9th International Multi-Conference on Society, Cybernetics and Informatics, Orlando: IMSCI Prentice Hall.

Rad. A.A. \& Benyoucef, M. (2010). A model for understanding social commerce. Conference on Information Systems Applied Research, Nashville Tennessee, USA, CONISAR Proceedings 3, 12-25. 
Roberts, B. \& Mackay, M. (1998). IT supporting supplier relationships: the role of electronic commerce. European Journal of Purchasing \& Supply Management, 4, 175-184.

Senecal, S., \& Nantel, J. (2004). The influence of online product recommendations on consumers' online choices. Journal of Retailing, 80(2), 159-169.

Sheikh, Z., Islam, T., Rana, S., Hameed, Z., \& Saeed, U. (2017). Acceptance of social commerce framework in Saudi Arabia. Telematics and Informatics, 34(8), 1693-1708.

Sheikh, S., Yezheng, L., Islam, T., Hameed, Z. \& Khan, I.U. (2019). Impact of social commerce constructs and social support on social commerce intentions. Information Technology \& People, 32 (1)

Shin, D.-H> (2010). The effects of trust, security and privacy in social networking: A security-based approach to understand the pattern of adoption. Interacting with Computers, 22, 428-438.

Simsek, S. (2012). Türkiye'de elektronik ticaret ve e-ticaretin kobiler üzerindeki etkisi. Yüksek Lisans Tezi, Istanbul Ticaret Üniversitesi, Sosyal Bilimler Enstitüsü.

Standifer, R. \& Wall, J. (2003). Managing e-commerce. Journal of Business Horizons, March-April.

Stephen, A. T., \& Toubia, O. (2010). Deriving value from social commerce networks. Journal of Marketing Research, 47(2), 215-228.

Venkatesh, V., Thong, J.I.L. \& Xu, X., (2012). Consumer acceptance and use of information technology: extending the unified theory of acceptance and use of technology. MIS Quarterly, 36(1), 157-178.

Wang, C. \& Zhang, P. (2012). The evolution of social commerce: the people, management, technology, and information dimensions. Communications of the Association for Information Systems, 31(5), 105-127.

Wang, C., Harris, J. \& Patterson, P. (2013). The roles of habit, self-efficacy, and satisfaction in driving continued use of selfservice technologies: A longitudinal study. Journal of Service Research, 16(3), 400-414.

Yılmaz, C \& Tümtürk, A. (2015) An investigation and a model suggestion for factors affecting online shopping intention using extended technology acceptance model. Yönetim Ve Ekonomi, 22(2).

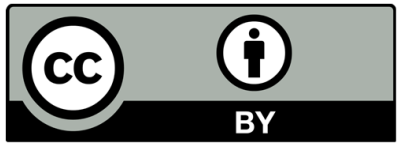

(C) 2021 by the authors; licensee Growing Science, Canada. This is an open access article distributed under the terms and conditions of the Creative Commons Attribution (CC-BY) license (http://creativecommons.org/licenses/by/4.0/). 